\title{
Optimalisasi Labor Fakultas Dakwah dengan Modul Praktikum
}

\author{
Novri Hardian ${ }^{1}$ \\ ${ }^{1}$ UIN Imam Bonjol Padang \\ Email : novri.hardian@yahoo.co.id
}

\begin{abstract}
Labor adalah sarana penunjang dalam praktek dakwah, dalam penelitian ini penulis akan menjelaskan urgensi labor fakultas dan penilaian berbagai pihak terhadap kegiatan di labor, hasil penelitian ini bersifat kualitatif (penggambaran tentang kejadian dan dialami mahasiswa dan dosen) penulis mengungkap begitu antusiasnya mahasiswa mengikuti praktek dilabor, fasiltas labor ada namun masih perlu ditambah agar lebih efektif dalam pelaksanaan praktek dakwah, birokrasi harus dimudahkan pula agar memudahkan semua pihak menggunakan fasilitas Labor, maka rancangan SOP labor dibutuhkan untuk menjawab hal tersebut.
\end{abstract}

Keyword : Labor, Dakwah, Praktikum

\section{PENDAHULUAN}

Untuk pelaksanaan aktualisasi
adalah peraturan yang terkait pelaksanaan diklat adalah peraturan pemerintah nomor 101 Tahun 2000 tentang Pendidikan dan Pelatihan Jabatan Pegawai Negeri Sipil (PNS). Peraturan ini menjelaskan bahwa salah satu jenis diklat yang strategis untuk mewujudkan PNS sebagai bagian dari ASN untuk menjadi lebih propesional adalah diklat dan pengajaran yang kemudian dikenal dengan latihan Dasar calon Aparatur Sipil Negera.

Lokus penulis dalam pelaksanaan aktualisasi dan agenda habituasi latihan dasar CPNS Golongan III angkatan pertama adalah fakultas Dakwah dan Ilmu Komunikasi Universitas Islam Negeri Imam Bonjol Padang.

\section{PEMBAHASAN}

\section{A. Pengertian}

Laboratorium (menurut KKBI ) adalah tempat atau kamar dan sebagainya tertentu yang dilengkapi dengan peralatan untuk mengadakan percobaan (penyelidikan dan sebagainya).

Makna kata laboratorium menjadi lebih spesifik ketika dirangkaikan dengan bidang atau objek studi tertentu. Sebuah ruangan di sekolah atau perguruan tinggi yang memiliki perlengkapan khusus untuk membantu mahasiswa mempelajari bahasa asing dengan cara mendengarkan pita rekaman, atau CD, atau menonton video atau DVD merekam diri mereka dan lain sebagainya.

Maka pengembangan labor dakwah dapat mengikuti konsep yang disebut di atas. Peralatan dan aktifitas mahasiswa pada sebuah labor dakwah sudah memenuhi standar standar minimal bila hal-hal yang disebutkan itu bisa dimiliki dan 
dikembangkan. Peralatan dan aktifitas tersebut membuat pendengaran mahasiswa lebih peka, penglihatan lebih cermat, analisis lebih tajam, keterampilan lebih teruji respon lebih tajam, keterampilan lebih teruji respon lebih tepat guna, dan produktifitas lebih tinggi terkait dengan dakwah.

Labor dakwah dapat dijabarkan sebagai kiat-kiat, teknik, panduan, juklak atau model-model dan format kegiatan yang bersifat kongkret. Harapannya adalah semakin banyak dihasilkan konsep-konsep terapan yang siap dipakai dilapangan akan semakin banyak praktisi yang siap bekerja untuk dakwah.

\section{B. Fungsi dan Manfaat Laboratorium}

Fungsi laboratorium yaitu sebagai sumber belajar dan mengajar, sebagai metode pengamatan dan metode percobaan, sebagai prasarana pendidikan atau sebagai wadahdalam proses belajar mengajar.Menurut Soejitno (1983) secara garis bersar laboratorium adalah sebagai berikut:

a. Memberikan kelengkapan bagi pelajaran teori yang telah diterima sehingga antara teori dan praktek bukan dua hal yang terpisah keduaduanya saling mengkaji dan saling mencari dasar.

b. Memberikan keterampilan kerja ilmiah bagi mahasiswa.

c. Memberikan dan memupuk keberanian untuk mencari hakikat kebenaran ilmiah darisesuatu obyek dalam lingkungan alam dan lingkungan sosial.

d. Menambah keterampilan dalam menggunakan alat dan media yang tersedia untuk mencari dan menemukan kebenaran. e. Memupuk rasa ingin tahu mahasiswa\&siswa sebagai modal sikap ilmiah seorang calon ilmuwan mengatakan bahwa melalui kegiatan praktikum yang biasanyadilakukan di laboratorium, siswa diharapkan dapat

f. Mengembangkan berbagai keterampilan secara terintegrasi.

g. Mengenal berbagai peralatan laboratorium.

h. Mengenal berbagai desain dan peralatan untuk eksperimen.

i. Mengembangkan keterampilan mengumpulkan dan menginterprestasikan data.

j. Mengembangkan sikap untuk melakukan sesuatu secara tepat dan akurat.

k. Mengembangkan keterampilan dalam mengobservasi.

l. Mengembangkan kemampuan dalam mengkomunikasikan hasil eksperimen

m. Mengembangkan kecakapan dalam menulis laporan.

n. Mengembangkan kemampuan untuk belajar dan melakukan percobaan sendiri.

o. Menambah keberanian berfikir sendiri dan menanggung resiko.

p. Merangsang berfikir siswa melalui eksperimen.

q. Mengembangkan keterampilan dalam memecahkan masalah dengan berbagai) variabel yang banyak dan berbagai kemungkinan pemecahannya

\section{Aktifitas labor Fakultas Dakwah}

Aktifitas menurut kamus bahasa indonesia, aktifitas adalah keaktifan, kegiatan-kegiatan, kesibukan atau bisa juga berarti kerja atau salah satu kegiatan kerja yang dilaksanakan tiap 
bagian dalam tiap organisasi dalam lembaga ${ }^{1}$, pada

a. Jurusan KPI

Komunikasi Penyiaran Islam (KPI), ini merupakan jurusan yang memanfaatkan media massa dan telekomukasi dan dakwah tabligh. Pemanfatan radio dakwah dan TV dakwah sangat mendukung kegiatan mahasiswa, selain itu menulis tulisan dimedia masa lokal maupun nasional perlu dilatih lebih propesional.

b. Jurusan BPI

Bimbingan penyuluhan Islam (BPI), labor yang berorientasi pada penyuluhan agama keluarga, individu dan kelompok

c. Jurusan MDI

Manajemen Dakwah Islam (MDI), labor yang menggunakan menggunakan sarana untuk peningkatan pengetahuan, seperti pelatihan manajemen ke masjidan, manajemen zakat, haji dan umrah.

d. Jurusan PMI

Pengembangan masyarakat Islam, menggunakan Dakwah development centre (DDC)

\section{Panduan tabligh mahasiswa dakwah UIN Imam Bonjol Padang}

Untuk melaksanakan praktek dakwah beberapa hal yang menjadi bahan perhatian adalah sebagai berikut:

\section{Media}

Media dakwah dari instrumen dilihat dari empat sifat, yaitu:

a. Media visual yaitu alat yang dapat dioperaskan untuk

\footnotetext{
${ }^{1}$ Departemen Pendidikan dan kebudayaan, Kamus besar Bahasa Indonesia, (Jakarta : Balai Pustaka 2004) h 17
}

kepentingan dakwah dengan melalui indera penglihatan seperti : film, slide, transparansi, over head, projektor, gambar, foto dan lain-lain

b. Media auditif yaitu alat-alat yang dapat dioperasikan sebagai saran penunjang dakwah yang dapat diungkap melalui indera pendengaran, radio, tape rekorder, telpon, telegram dan lain sebagainya

c. Media audio visual yaitu alat-alat dakwah yang dapat didengar juga sekaligus dilihat, seperti movie film, televisi, video dan sebagainya. Media cetak yaitu cetakan dalam bentuk tulisan dan gambar sebagai pelengkap informasi tulis, seperti buku, surat kabar, majalah, buletin dan lain sebagainya (Hasanuddin : 1996, 44)

Pada praktek dakwah yang di perlukan di labor fakultas dakwah adalah :

$>$ Mimbar

$>$ Mic

$>$ Sound

$>$ Kamera

$>$ Kertas

$>$ Alat tulis

2. Praktek tabligh
a. Menyiapkan topik pembahasan
b. Membuka acara dan jenis - jenis pembukaan
c. Menjelaskan dalil yang akan diuraikan
d. Menjelaskan secara sitematis dari umum kekhusus atau khusus ke umum
e. Mencari humor sederhana
f. Memakai kata menggugah 
g. Rekaman : Simulasi khutbah, ceramah dan diskusi keagamaan yang dilakukan mahasiswa

h. Kisah yang menarik

i. Kesimpulan dan penguatan

\section{Lembar evaluasi}
a. Angket
b. Wawancara
c. Hasil rekaman

\section{E. Topik dan pembahasan dakwah.}

(terlampir dalam modul ini)

\section{F. Rekayasa da'i masa depan}

Da'i masa depan perlu ada menjawab kebutuhan ummat sebab tidak mungkin dapat terlaksana tampa adanya pembinaan yang berkala dan baik

a. Aspek baca al-Qur'an

Membaca al-Qur'an dengan tajwid yang benar, dibawakan dengan irama yang menarik dapat meningkatkan perhatian jama'ah dibanding yang biasa saja. Tentu pelatihan dibutuhkan untuk meningkatkan kapasitas mahasiswa, ada ust yang terkenal dengan suara yang indah seperti ust UJE (Jeffri al Bukhori) yang terkenal dengan senandungnya pada masa terkenalnya. Bahkan takbiran UJE sangat populer diputarkan disetiap hari lebaran.

b. Penguasaan bahasa arab

Keahlian dan kepastian mengucapkan kata-kata berupa kalimat bahasa arab tentu dapat memberikan perhatian lebih dari audiens. Kemampuan berbahasa yang baik tentu akan dapat meningkatkan keyakinan audiens, seperti ust syekh ali jaber yang noat bene arab yang lancar berbahasa indonesia dia memberikan penjelasan yang detail tentang maksud bahasa arab yang digunakan

c. Kualitas pemahaman hadist Kuantitas dan kualitas mengusai hadist dapat dibekali dengan membiasakan untuk membawakan hadist yang bervariasi. Kemapuan menjelaskan hadist dibutuhkan bagi mahasiswa, seorang ustadz ahli hadist seperti abdul somad menjadi inspirasi keparakarannya dengan ingatnya yang kuat untuk dapat menjelaskan perawi hadsit matan dan penjelasan para ulama.

d. Kemapuan menyusun materi dakwah

Adanya tema dan pembahasan yang runtut dan juga berkelanjutan menjadikan audiens mengikuti ritme yang disusun. Kita lihat bagaimana ust yusuf mansur yang ciri khas menyusun dakwah dengan cerita pengalaman hidup orang secara detail dan menarik mampu menjadi daya tarik tersendiri. Artinya kemampuannya dalam menyusun materi dapat dinilai sebagai hal yang baik.

e. Kemampuan mengusai massa Serius saja dari awal hingga akhir tentu tidak baik sebab bisa membuat jenuh dan konsentrasi manusia juga terbatas butuh humor ringan untuk menghidupkan kembali kelelahan. Kita lihat ust Zainuddin MZ kemampuannya dalam mengusai masa yang banyak dengan kelakar yang menarik dapat sambutan luar biasa, bahkan setiap kata yang diucapkan dapat disambung 
penonton sehingga mengikuti apa yang dia sampaikan.

f. Kemapuan menceritakan kisah yang berkesan

Kemampuan untuk menjelaskan kisah-kisah orang sholeh dan juga berupaya untuk mencari informasi pengalaman hidup, sebagai contoh ustdz Yusuf Mansur yang dapat menceritakan tentang pengalaman hidup orang yang sholeh menjadi motivasi untuk dapat membangkitkan semangat hidup dan pengalaman.

Maka dari pengalaman penulis setelah melakukan penilitian dan praktek ternyata dakwah menoton tidak menarik perhatian publik, sepert belakangan ini banyak artis terkenal karena dapat menguasai massa yang kadang jenuh dengan dakwah yang selalu serius dari awal hingga akhir.

\section{G. Panduan mengangkat acara} pelatihan Khatib IMP Kota Padang bekerjasama dengan Labor Fakultas Dakwah

Buku panduan ini berisi apasaja yang harus disiapkan dalam membuat acara mulai dari membuat SK, proposal acara, undangan, laporan keuangan, sertifkat dan terkait dengan acara. (buku khusus yang sudah pernah disusun oleh penulis)

\section{H. Catatan dan diskusi di labor fakultas Dakwah}
a. Menurut mahasiswa yang mengikuti pelatihan praktikum perlu diadakan sosialiasi untuk menjelaskan fungsi labor
b. Selanjutnya menurut mereka bimbingan dilakukan pada

siapa saja, mereka menjawab kepada seluruh civitas fakultas Dakwah

c. Apakah labor fakultas Dakwah memiliki sarana prasarana yang cukup mereka menjawab masih lengkap, walau belum cukup

d. Penelitian dan pengabdian masyarakat sangat berkaitan erat dengan kualitas pelaksanaan praktikum labor (Kuisener tentang sosialisasi, praktek tabligh, bimtek pada saat pelaksaan di labor Fakultas Dakwah, Juli-Oktober 2018)

\section{SOP Praktek Labor dakwah}

\section{Latar Belakang}

Secara operasional wujud peningkatan kualitas pelayanan kepada masyarakat adalah berupa perbaikan proses penyelenggaraan administrasi pemerintahan sehingga lebih mencerminkan birokrasi yang mampu menjalankan fungsi pelayanan umum yang berkualitas, memuaskan, transparan dan dapat dipertanggung jawabkan.

Sebagai upaya untuk mewujudkan peningkatan tersebut, diperlukan ketersediaan Standar Operasional Prosedur (SOP) sebagai pedoman/ petunjuk bagi para aparatur dalam melaksanakan tugas pelayanan dan bagi masyarakat pengguna layanan (pelanggan) untuk mengetahui/memahami akan suatu prosedur layanan yang dilakukan aparatur. Dengan demikian dapat dihindarkan tumpang tindih tanggung jawab dan kesalahan prosedur dalam melaksanakan tugas. 


\section{Tujuan}

Pengunaan pedoman
umum pelayanan (SOP) in disusun untuk mendorong setiap unit kerja dilingkungan Agama untuk menyusun SOP baik dalam penyelenggaraan tugas dan fungsi maupun dalam memberikan pelayanan kepada masyarakat

SOP yang disusun oleh setiap satuan organisasi/kerja diharapkan :

a. Memberikan kepastian dan keseragaman dalam proses pelaksanaan suatu tugas

b. Menunjang kelancaran dalam proses pelaksanaan tugas dan kemudahan pengendalian

c. Mempertegas tanggung jawab dalam pelaksanaan tugas bagi aparatur

d. Meningkatkan daya guna dan hasil guna secara berkelanjutan dalam melaksanakan tugas umum pemerintahan

e. Memberikan informasi mengenai pelaksanaan tugas yang dilakukan oleh aparatur pemerintah secara propesional

f. Memberikan kejelasan dan transparansi kepada masyarakat sebagai penerima layanan mengenai hak dan kewajibannya/

\section{Manfaat}

a. Standarisasi cara yang harus dilakukan dalam menyelesaikan pekerjaan mengurangi kesalahan atau kelalaian

b. Menjamin proses yang telah ditetapkan dan dijadwalkan dapat berlangsung sebagaimana mestinya c. Menjamin tersedianya data untuk menyempurnakan proses

d. Meningkatkan akuntabilitas dengan melaporkan dan mendokumentasikan hasil dalam pelaksanaan tugas

e. Memberikan cara konkrit untuk perbaikan kerja

f. Menghindari terjadinya variasi proses pelaksanaan kegiatan dan tumpang tindih

g. Membantu pegawai lebih mandiri

h. Membantu mengidentifikasi apabila terjadi kesalahan prosedural

i. Memudahkan penelusuran terjadinya penyimpangan dan memudahkan langkah perbaikan

\section{SOP PRAKTEK DAKWAH DI LABOR FAKULTAS DAKWAH}

1. Dosen membuat surat kepada ke Dekan Fakultas Dakwah dan Ilmu Komunikasi cq Ketua Labor Fakultas Dakwah dan Ilmu Komunikasi UIN Imam Bonjol Padang

2. Bagian Tata usaha menerima surat dan mencatat dilembar disposisi untuk dilanjutkan ke ketua labor Fakultas Dakwah dan Ilmu Komunikasi UIN Imam Bonjol Padang

3. Ketua labor berkoordinasi dengan Dekan Fakultas dakwah untuk mempertimbangkan surat yang diajukan

4. Dosen yang mengajukan permohonan mencek surat yang sudah masuk untuk ditindak lanjuti

5. Dosen memakai perlengkapan labor sesuai dengan permohonan yang dimasukkan

6. Merapakan kembali fasilitas labor untuk menjaga dan memelihara fasilitas yang dipakai 
7. Meninggalkan bukti tertulis kegaitan yang dilaksanakan dan membuat daftar hadir dosen dan mahasiswa yang mengikuti kegiatan

Membuat daftar catatan yang berisi tentang hal-hal yang telah dilakukan dan masukan untuk kemajuan labor fakultas Dakwah, informasi ini diserahkan ke ketua labor dan dekan fakultas Dakwah.

\section{HASIL PENELITIAN}

A. Melakukan koordinasi dengan pimpinan

1. Tahapan Pertama; Melakukan pertemuan dengan Dekan fakultas dakwah untuk melaporkan sekaligus meminta izin Optimalisasi Labor Fakultas Dakwah dan ilmu komunikasi melalui Modul Fakultas Dakwah Analisa Dampak; Terlaksananya diskusi dengan pimpinan fakultas dakwah dan Ilmu komunikasi nilai-nilai ANEKA yang ada pada kegiatan ini yaitu Wog: Koordinasi dalam rencana kegiatan adanya koordinasi dan kolaborasi dengan dekan Fakultas Dakwah dan ilmu Komunikasi UIN Imam Bonjol Padang dalam membuat modul praktikum

2. Tahapan Kedua Membuat kesepakatan dengan pimpinan Fakultas Dakwah

Analisa Dampak; Terwujudnya kesepakatan dengan pimpinan Fakultas Dakwah dan Ilmu Komunikasi UIN Imam Bonjol Padang nilai-nilai ANEKA yang ada pada kegiatan ini yaitu Etika Publik : bersikap sopan, santun, persuasif dalam melakukan paparan informal mengenai tindak lanjut kegiatan dalam perencanaan
3. Tahapan Ketiga Menyusun jadwal tentang pelaksanaan kegiatan

Analisa Dampak : Adanya rencana (jadwal) tentang pelaksanaan kegiatan nilai-nilai ANEKA yang ada pada kegiatan ini yaitu Akuntabilitas : tanggung jawab rancangan modul praktikum dakwah Anti korupsi : disiplin dalam memulai rapat, memantau kejujuran, kepatuhan

\section{Dampak Umum Bagi Instansi.}

Dengan melakukan koordinasi kepada Atasan dan Dosen-dosen lainnya, menjadi bukti kesolidan dan saling respek di antara sivitas akademika UIN Imam Bonjol Padang memperkuat visi fakultas dakwah Visi "Menjadi pusat pendidikan dan pengkajian dalam mengembangkan ilmu dakwah dan komunikasi di kawasan Sumatera tahun 2025"

B. Membuat Standar Operasional Prosedural (SOP) Labor Fakultas Dakwah dan Ilmu Komunikasi UIN Imam Bonjol Padang

1. Tahapan Pertama; Membaca SOP Labor Fakultas Dakwah dan Ilmu Komunikasi UIN Imam Bonjol Padang

Analisa Dampak; Adanya SOP rujukan dari UIN Imam Bonjol Padang sehingga di jadikan dasar berpijak nilai-nilai ANEKA yang ada pada kegiatan ini yaitu Akuntabilitas : tanggung jawab dalam penyelesaian SOP Labor dakwah dan integritas bersama dengan tugas yangg telah disepakati bersama

2. Tahapan Kedua Rapat penyusunan SOP Labor Fakultas Dakwah dan Ilmu Komunikasi UIN Imam Bonjol Padang

Analisa Dampak; Tersusunnya SOP Labor Fakultas Dakwah dan Ilmu 
Komunikasi UIN Imam Bonjol Padang nilai-nilai ANEKA yang ada pada kegiatan ini yaitu Wog : Koordinasi dalam rencana kegiatan adanya koordinasi dan kolaborasi dosen dakwah dalam membuat SOP labor Fakultas dakwah

Nasionalisme: Penyampaian paparan dengan menjunjung azas musyawarah mengenai tindak lanjut kegiatan dengan tetap bersikap terbuka dengan saran dan kritik informal mengenai tindak lanjut kegiatan dalam perencanaan

3. Tahapan Ketiga Menyimpulkan rancangan SOP Labor Fakultas Dakwah dan Ilmu Komunikasi UIN Imam Bonjol Padang

Analisa Dampak: Tersedianya SOP Labor Fakultas Dakwah dan Ilmu Komunikasi UIN Imam Bonjol Padang nilai-nilai ANEKA yang ada pada kegiatan ini yaitu Anti korupsi : disiplin dalam memulai rapat, memantau kejujuran, kepatuhan membuat SOP

Etika Publik : bersikap sopan, santun, persuasif dalam melakukan paparan informal mengenai tindak lanjut kegiatan dalam perencanaan

Dampak Umum Bagi Instansi.

Dengan melakukan koordinasi kepada Atasan dan Dosen-dosen lainnya, menjadi bukti kesolidan dan saling respek di antara sivitas akademika UIN Imam Bonjol Padang Melakukan Sosialisasi kegiatan labor fakultas Dakwah "Menjadi pusat pendidikan dan pengkajian dalam mengembangkan ilmu dakwah dan komunikasi di kawasan Sumatera tahun 2025”

C Melakukan Sosialisasi kegiatan Labor Fakultas Dakwah dan Ilmu Komunikasi UIN Imam Bonjol Padang
1. Tahapan Pertama; Koordinasi pimpinan tentang sosialisasi Labor Fakultas Dakwah dan Ilmu Komunikasi UIN Imam Bonjol Padang

Analisa Dampak; Kesepakatan pimpinan tentang sosialisasi Labor Fakultas Dakwah dan Ilmu Komunikasi UIN Imam Bonjol Padang nilai-nilai ANEKA yang ada pada kegiatan ini yaitu Wog : Koordinasi dalam rencana kegiatan adanya koordinasi dan kolaborasi dosen dakwah dalam membuat SOP labor Fakultas dakwah Nasionalisme: Penyampaian paparan dengan menjunjung azas musyawarah mengenai tindak lanjut kegiatan dengan tetap bersikap terbuka dengan saran dan kritik

2. Tahapan Kedua Membuat undangan sosialisasi Labor Fakultas Dakwah dan Ilmu Komunikasi UIN Imam Bonjol Padang

Analisa Dampak; Tersusunnya Tersedianya undangan sosialisasi Labor Fakultas Dakwah dan Ilmu Komunikasi UIN Imam Bonjol Padang nilai-nilai ANEKA yang ada pada kegiatan ini yaitu Menjaga etika komunikasi dengan memberikan undangan peserta sosialisasi

3. Tahapan Ketiga Membuat slide sosialisasi optimalisasi Labor Fakultas Dakwah dan Ilmu Komunikasi UIN Imam Bonjol Padang

Analisa Dampak: Tersedianya slide sosialisasi optimalisasi Labor Fakultas Dakwah dan Ilmu Komunikasi UIN Imam Bonjol Padang. Nilai-nilai ANEKA yang ada pada kegiatan ini yaitu 
Akuntabilitas : tanggung jawab slide sosialisasi optimalisasi labor fakultas Dakwah dan Ilmu Komunikasi UIN Imam Bonjol Padang

4. Tahapan Keempat : Sosialisasi Labor Fakultas Dakwah dan Ilmu Komunikasi UIN Imam Bonjol Padang

Analisa Dampak : terlaksananya Sosialisasi Labor Fakultas Dakwah dan Ilmu Komunikasi UIN Imam Bonjol Padang. Nilai-nilai ANEKA yang ada pada kegiatan ini yaitu Anti korupsi :_disiplin dalam memulai rapat, memantau kejujuran, kepatuhan kegiatan sosialisasi

5. Tahapan Keempat : Evaluasi Sosialisasi Labor Fakultas Dakwah dan Ilmu Komunikasi UIN Imam Bonjol Padang

Analisa Dampak : terlaksananya evaluasi Sosialisasi Labor Fakultas Dakwah dan Ilmu Komunikasi UIN Imam Bonjol Padang. Nilai-nilai ANEKA yang ada pada kegiatan ini yaitu Nasionalisme: Penyampaian paparan dengan menjunjung azas musyawarah mengenai tindak lanjut kegiatan dengan tetap bersikap terbuka dengan saran dan kritik

Dampak Umum Bagi Instansi.

Dengan melakukan koordinasi kepada Atasan dan Dosen-dosen lainnya, menjadi bukti kesolidan dan saling respek di antara sivitas akademika UIN Imam Bonjol Padang Melakukan Sosialisasi kegiatan labor fakultas Dakwah "Menjadi pusat pendidikan dan pengkajian dalam mengembangkan ilmu dakwah dan komunikasi di kawasan Sumatera tahun 2025"

D. Menyusun Bimbingan teknis Labor Fakultas Dakwah dan Ilmu Komunikasi UIN Imam Bonjol Padang

1. Tahapan Pertama; Koordinasi pimpinan Labor Fakultas Dakwah dan Ilmu Komunikasi UIN Imam Bonjol Padang

Analisa Dampak; terlaksananya Koordinasi pimpinan Labor Fakultas Dakwah dan Ilmu Komunikasi UIN Imam Bonjol Padang nilai-nilai ANEKA yang ada pada kegiatan ini yaitu Wog_: Koordinasi dalam rencana kegiatan adanya koordinasi dan kolaborasi dosen dakwah dalam membuat Bimbingan teknis labor Fakultas dakwah

2. Tahapan Kedua Membuat undangan bimbingan Labor Fakultas Dakwah dan Ilmu Komunikasi UIN Imam Bonjol Padang

Analisa Dampak; Tersedianya Membuat undangan bimbingan Labor Fakultas Dakwah dan Ilmu Komunikasi UIN Imam Bonjol nilai-nilai ANEKA yang ada pada kegiatan ini yaitu Menjaga etika komunikasi dengan memberikan undangan peserta bimbingan teknis

3. Tahapan Ketiga Bimbingan Teknis Labor Fakultas Dakwah dan Ilmu Komunikasi UIN Imam Bonjol Padang

Analisa Dampak: Terlaksananya Bimbingan Teknis Labor Fakultas Dakwah dan Ilmu Komunikasi UIN Imam Bonjol Padang. Nilai-nilai ANEKA yang ada pada kegiatan ini yaitu Anti korupsi :disiplin dalam 
memulai rapat, memantau kejujuran, kepatuhan pelaksanaan bimbingan teknis

Dampak Umum Bagi Instansi. Dengan melakukan koordinasi kepada Atasan dan Dosen-dosen lainnya, menjadi bukti kesolidan dan saling respek di antara sivitas akademika UIN Imam Bonjol Padang Melakukan Sosialisasi kegiatan labor fakultas Dakwah "Menjadi pusat pendidikan dan pengkajian dalam mengembangkan ilmu dakwah dan komunikasi di kawasan Sumatera tahun 2025"

E. Mengumpulkan referensi Materi dakwah untuk modul praktikum dakwah

1. Tahapan Pertama; Membaca materi Dakwah untuk modul praktikum dakwah

Analisa Dampak; paham materi Dakwah untuk modul praktikum dakwah nilai-nilai ANEKA yang ada pada kegiatan ini yaitu Akuntabilitas : tanggung jawab materidakwah yang diterapkan di labor fakultas Dakwah UIN Imam Bonjol Padang

2. Tahapan Kedua Rapat penyusunan Materi Dakwah untuk modul praktikum dakwah

Analisa Dampak; Terlaksananya rapat penyusunan Materi Dakwah untuk modul praktikum dakwah. Nilai-nilai ANEKA yang ada pada kegiatan ini yaitu Anti korupsi :disiplin dalam memulai rapat, memantau kejujuran, kepatuhan

3. Tahapan Ketiga Menyimpulkan rancangan Materi dakwah untuk modul praktikum dakwah
Analisa Dampak: Tersusunnya Materi dakwah untuk modul praktikum dakwah. Nilai-nilai ANEKA yang ada pada kegiatan ini yaitu Akuntabilitas : tanggung jawab materi praktek fakultas Dakwah UIN Imam Bonjol Padang

\section{Dampak Umum Bagi Instansi.}

Dengan melakukan tanggung jawab, akuntabilitas akan menjadikan suasana akademika UIN Imam Bonjol Padang yang bisa berkompentensi di dalam lembaga lebih baik "Menjadi pusat pendidikan dan pengkajian dalam mengembangkan ilmu dakwah dan komunikasi di kawasan Sumatera tahun 2025"

F. Praktek Dakwah di Labor Fakultas Dakwah dan Ilmu Komunikasi UIN Imam Bonjol Padang

1. Tahapan Pertama; Koordinasi pimpinan untuk praktek dakwah di Labor Fakultas Dakwah dan Ilmu Komunikasi UIN Imam Bonjol Padang

Analisa Dampak; terlaksananya koordinasi pimpinan untuk praktek dakwah di Labor Fakultas Dakwah dan Ilmu Komunikasi UIN Imam Bonjol Padang. Nilai-nilai ANEKA yang ada pada kegiatan ini yaitu Wog: Koordinasi dalam rencana kegiatan adanya koordinasi dan kolaborasi dosen dakwah dalam Praktek Dakwah di labor Fakultas dakwah

2. Tahapan Kedua praktek dakwah di Labor Fakultas Dakwah dan Ilmu Komunikasi UIN Imam Bonjol Padang

Analisa Dampak; Terlaksananya Bimbingan praktek dakwah di Labor Fakultas Dakwah dan Ilmu 
Komunikasi UIN Imam Bonjol Padang. Nilai-nilai ANEKA yang ada pada kegiatan ini yaitu Anti korupsi :disiplin dalam memulai rapat, memantau kejujuran, kepatuhan

Dampak Umum Bagi Instansi.

Dengan melakukan koordinasi, tanggung jawab, akuntabilitas akan menjadikan suasana akademika UIN Imam Bonjol Padang yang bisa berkompentensi di dalam lembaga lebih baik "Menjadi pusat pendidikan dan pengkajian dalam mengembangkan ilmu dakwah dan komunikasi di kawasan Sumatera tahun 2025"

G. Validasi Praktek Dakwah di labor Fakultas Dakwah dan Ilmu Komunikasi UIN Imam Bonjol Padang

1. Tahapan Pertama; Koordinasi dosen Labor Fakultas Dakwah dan Ilmu Komunikasi UIN Imam Bonjol Padang

Analisa Dampak; terlaksananya Koordinasi dengan dosen labor praktek dakwah di Labor Fakultas Dakwah dan Ilmu Komunikasi UIN Imam Bonjol Padang. Nilai-nilai ANEKA yang ada pada kegiatan ini yaitu Menjaga etika komunikasi dengan menyiapkan segala sesuatu yang digunakan untuk validasi praktek dakwah

2. Tahapan Kedua Menyiapkan materi dakwah di Labor Fakultas Dakwah dan Ilmu Komunikasi UIN Imam Bonjol Padang

Analisa Dampak; Menyiapkan bahan yang divalidasi di Labor Fakultas Dakwah dan Ilmu Komunikasi UIN Imam Bonjol Padang. Nilai-nilai ANEKA yang ada pada kegiatan ini yaitu Akuntabilitas : tanggung jawab materi praktek fakultas Dakwah UIN Imam Bonjol Padang

Tahapan Ketiga Evaluasi Validasi praktek dakwah

Analisa Dampak; terevaluasi Validasi praktek dakwah di Labor Fakultas Dakwah dan Ilmu Komunikasi UIN Imam Bonjol Padang. Nilai-nilai ANEKA yang ada pada kegiatan ini yaitu Anti korupsi :disiplin dalam memulai rapat, memantau kejujuran, kepatuhan

\section{Dampak Umum Bagi Instansi.}

Dengan melakukan koordinasi, tanggung jawab, akuntabilitas akan menjadikan suasana akademika UIN Imam Bonjol Padang yang bisa berkompentensi di dalam lembaga lebih baik "Menjadi pusat pendidikan dan pengkajian dalam mengembangkan ilmu dakwah dan komunikasi di kawasan Sumatera tahun 2025"

\section{KESIMPULAN}

Dakwah dalam perspektif al-Qur'an dan hadist sudah dapat menjelaskan unsurunsur dakwah baik dari segi da'i, mad'u, media, Metode dan tujuan dakwah sehingga dapat digunakan dalam tantanan praktis dalam pelaksanaan dakwah.

Dalam pelaksanaan dakwah harus merujuk pada sumber yang kuat, salah satunya al-Qur'an dan Hadist. Sebenarnya persoalan dakwah sudah ada sejak zaman dahulu sekaligus dengan penyelesaiaanya tetapi perlu dilihat lagi secara kontektual, sesuai dengan tantangan zaman sekarang ini.

\section{DAFTAR KEPUSTAKAAN}

\section{A. Buku atau Modul}


Hasanuddin, Hukum dakwah Tinjauan aspek hukum dalam berdakwah di indonesia, Jakarta : Pedoman Ilmu Jaya, 1996

Lembaga Administrasi Negara Republik Indonesia. 2015. Akuntabilitas: Modul Pendidikan dan Pelatihan Prajabatan Golongan III. Jakarta: Lembaga Administrasi Negara Republik Indonesia.

Lembaga Administrasi Negara Republik Indonesia. 2015. Nasionalisme: Modul Pendidikan dan Pelatihan Prajabatan Golongan III. Jakarta: Lembaga Administrasi Negara Republik Indonesia.

Lembaga Administrasi Negara Republik Indonesia. 2015. Etika Publik: Modul Pendidikan dan Pelatihan Prajabatan Golongan III. Jakarta: Lembaga Administrasi Negara Republik Indonesia.

Lembaga Administrasi Negara Republik Indonesia. 2015. Komitmen Mutu: Modul Pendidikan dan Pelatihan Prajabatan Golongan III. Jakarta: Lembaga Administrasi Negara Republik Indonesia.

Lembaga Administrasi Negara Republik Indonesia. 2015. Anti Korupsi: Modul Pendidikan dan Pelatihan Prajabatan Golongan III. Jakarta: Lembaga Administrasi Negara Republik Indonesia.

Peraturan Kepala Lembaga Administrasi Negara Nomor 15 Tahun 2015 tentang Penyelenggaran Pendidikan dan Pelatihan Prajabatan Calon Pegawai Negeri Sipil Golongan III.
Lembaga Administrasi Negara, Modul pelatihan dasar Calon CPNS, Whole of goverment, 2017, Jakarta : Lembaga Administrasi Negara Republik Indonesia

Lembaga Administrasi Negara, Modul pelatihan dasar Calon CPNS, Pelayan Publik , 2017, Jakarta : Lembaga Administrasi Negara Republik Indonesia

Lembaga Administrasi Negara, Modul pelatihan dasar Calon CPNS, Manajemen ASN, 2017 Jakarta : Lembaga Administrasi Negara Republik Indonesia

SOP UIN IB Padang, lampiran keputusan menteri Agama republik indonesia no 168 tahun 2010 tentang pedoman penyusunan standar operasional prosedur dilingkungan kementerian Agama

\section{B. Peraturan pemerintah}

Peraturan Pendayagunaan Aparatur Negara dan Reformasi Birokrasi Nomor 17 Tahun 2013 tentang Jabatan Fungsional Dosen dan Angka Kreditnya

Undang Undang No 5 Tahun 2014 tentang ASN

Undang-Undang No 25 tahun 2009 tentang pelayanan Publik

Panduan Studi Lapangan, Balai Pelatihan Keagamaan Padang, 2018

Undang-undang no 43 tahun 1999, Tentang perubahan atas undangundang no 8 Tahun 1974, tentang pokok-pokok kepegawaian 
Peraturan Kepala BKN No. 24

Tahun 2017

PP 53 tahun 2010, tentang disiplin PNS

PP 46 Tahun 2011 dan Perka no 1 Tahun 2013, Tentang Penilaian

Prestasi Kerja Pegawai Negeri Sipil

PP 12 Tahun 2002, Penghargaan yg diberikan atas prestasi kerja \& pengabdian PNS terhadap negara.

\section{Sumber Internet}

www. uinib.ac.id

fdk.uinib.ac.id 